\title{
Influence of Seasons and Varieties on Vase Life of Gerbera (Gerbera jamesonii Hook.) Cut Flower
}

\author{
Anil Kumar Acharya ${ }^{1}$, Dilli Ram Baral' ${ }^{2}$, Durga Mani Gautam² and Umed Kumar Pun ${ }^{3}$ \\ ${ }^{1}$ Department of Agriculture, Hariharbhawan, Lalitpur \\ ${ }^{2}$ Institute of Agriculture and Animal Sciences, Rampur, Chitwan \\ ${ }^{3}$ Himalayan Flora Enterprises Pvt. Ltd., Lalitpur \\ e-mail: anil-acharya@hotmail.com
}

\begin{abstract}
Postharvest studies were carried out in three varieties of (Gerbera jamesonii Hook.) cvs. Primrose, Malibu and Sunway to find out the effect of growing seasons (autumn, winter and spring) on the vase life of cut flowers during September 2009 to March 2010. Laboratory experiments were carried out in controlled room having $18 \pm 2^{\circ} \mathrm{C}$ temperature, $68 \pm 2 \%$ relative humidity and 100 lux light. The study revealed that the longest vase life was noticed in Sunway, followed by Primrose and Malibu. Regarding the season of production, longest vase life (18.37 days) was found in the flowers harvested in winter, followed by spring (14.8 days) and autumn (9.57 days). The interaction effect of season and variety showed that longest vase life (23.2 days) was found in Sunway harvested in winter whereas the shorter vase lives (5.7 and 7.8 days) were in Malibu and Primrose respectively harvested in autumn. Stalk length $(57.88 \mathrm{~cm})$ and floral diameter $(10.78 \mathrm{~cm})$ were highest in autumn while diameter of the stalk $(0.64 \mathrm{~cm})$ was the highest in spring. Sunway had the highest floral and stalk diameters, while the stalk length was longer in Malibu and Primrose. Total water uptake during the vase life was highest in flowers grown in winter (34.9 ml), followed by spring ( $34.7 \mathrm{ml})$ and autumn $(26.14 \mathrm{ml})$.
\end{abstract}

Key words: floral diameter, floriculture, postharvest, vase life, water uptake

\section{Introduction}

Nepal has predominantly an agriculture-based economy where floriculture sub-sector holds a great export potential. In Nepal, commercial flower production is initiated and has been expanded to 34 districts throughout the country. Also, the production area under floriculture is gradually increasing throughout the country. This sector provides employment opportunities to about 2,500 people among which $60 \%$ of them are women (FAN 2007). Floriculture in Nepal has been converted into an established business over a period of one and half decade (14-15 years). It was observed that the total turn over of this sector in 2006 was about 230 million rupees (FAN 2007) which grew to 560 million rupees in 2009 (FAN 2010). Nepalese cut flowers stand at one of the most prioritized position in international market as compared to other agricultural products in terms of export market potential (UNCTAD/WTO 2007).
Gerbera (Gerbera jamesonii Hook.) is one of most important cut flowers in Nepal. It is in considerable demand in both domestic and export markets. The daily demand of gerbera in Kathmandu is 1500-3000 sticks and cost of one stick gerbera is Rs.15.0. The area of gerbera cultivation in Nepal is 0.25 ha (MOAC 2009). Since the past 2-3 years, the domestic supply could not fulfill the total demand of gerbera and about $65 \%$ of the total demand was supplied by importing from India.

Gerbera also known as Transvaal daisy or Barberton daisy, is a member of the Composite family. Flowers of gerbera are available in a wide range of colors, including yellow, orange, pink, crimson, red, purple and white. Gerbera is most commonly used worldwide as a cut flower (Emongor 2004). Gerbera is one of the ten most popular commercial cut flower in the world and 
according to the global trends in floriculture, it occupies the fourth place among cut flowers (Choudhary \& Prasad 2000). The blooms are attractive, suitable for any type of floral arrangements and are available in different shades and hues. Besides floral arrangements, gerbera is widely used in bouquets and in dry flower crafts (Nair et al. 2003).

Keeping quality is an important parameter for evaluation of cut flower quality, for both domestic and export markets. The techniques of prolonging the vaselife of flowers will be a great asset to the growers and users (Nair et al. 2003). Keeping quality of flowers is affected by internal as well as external factors. The internal factors which are responsible for the keeping quality of cut blooms are the rate of water absorption and transpiration. Respiration is another internal factor that affects the life of the cut flower. Some environmental factors such as temperature, relative humidity and wind velocity also affect cut flower life (Meman \& Dabhi 2006).

Generally gerbera is grown during Falgun-Chaitra (February-March) or Shrawan-Bhadra (July-August) in Kathmandu valley and production starts after 3 months of planting. In winter, especially, from OctoberFebruary (Kartik-Falgun), there is high demand and low supply of cut flowers. Flower growers bring most of their domestic products (gerbera, carnation, gladiolus, Dutch rose) in the market after March-April (Chaitra-Baisakh) and do not get high price due to large supply. Besides, the problem with gerbera cut flowers is the short postharvest life (Wernett et al. 1996). Low production due to fungal diseases and high postharvest losses due to lack of postharvest treatment are the burning problems of gerbera production and marketing in Nepal.

No research has yet been done on postharvest aspects of gerbera in Nepal. There is a need to develop a technology in gerbera for better keeping quality of the produce. Some parameters, for determining the vase life of the flower, like seasonal variation of flower quality, variation in quality production at different locations or growers, and varietals performance must be known for flower marketing. Being the exportable cut flower commodity, these parameters are prerequisites for floriculture industry. Therefore, the research was carried out to determine the influence of location, season, variety, and vase solutions for longevity of gerbera cut flower. The paper focuses on influence of seasons and varieties on vase life of gerbera cut flower.

\section{Methodology}

The vase life study was conducted at the laboratory of Seed Quality Control Centre, Ministry of Agriculture and Cooperatives, Hariharbhawan, Lalitpur, Nepal during September 2009 (Mid Bhadra) to March 2010 (End of Falgun). Flowers were kept in a controlled room having $20 \pm 2{ }^{\circ} \mathrm{C}$ temperature and $68 \pm 2 \%$ relative humidity for vase life evaluation. The light was measured by Digital Lux meter (LX-101, Lutron Company, Taiwan) and light was maintained at 100 lux (on an average) throughout the study period.

In the experiment, three varieties of gerbera were evaluated grown in three seasons i.e. autumn (September/Bhadra-Ashoj), winter (December/ Mangsir-Poush, and spring (February-March/FalgunChaitra). The varieties were Sunway, Primrose and Malibu of Florist Company, Holland.

In the laboratory, after checking and rejecting abnormal, diseased and damaged flowers, the scape (stalk) of the selected flowers having $30 \mathrm{~cm}$ stalk with slant cutting at the base were kept in $250 \mathrm{ml}$ conical flask by filling $200 \mathrm{ml}$ distilled water. After keeping flower stalk in the solution, the top of the conical flask was wrapped up with aluminum foil to prevent evaporation loss. Vernier caliper was used to measure the diameter of the flower's stalk and floral diameter was measured with the help of measuring scale.

The treatments were laid out in a randomized complete block design (RCBD) with 5 replications. After placing the stalk of the flower in the conical flask containing distilled water, water level in the flask was marked with a permanent marker. Water uptake was measured at 2 days interval of vase life with the help of 5, 2 and $1 \mathrm{ml}$ syringes. The added volume of water at the marked point after 2 days interval was considered as the water uptake of the flower.

Flower quality was evaluated on the visual basis of 5-1 point scale. Grade 5 was considered as the best quality of the flower whereas grade 1 as vase life termination stage. Stalk of the flower was examined visually for the sign of rotting. Senescence stages of flower on the basis of visual observations are given in Fig. 1. 


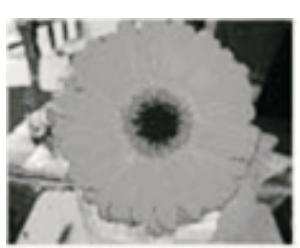

1
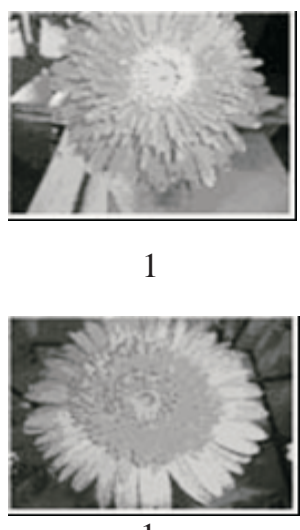

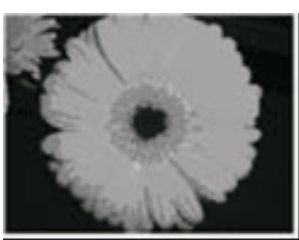

2

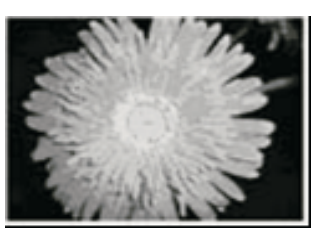

2

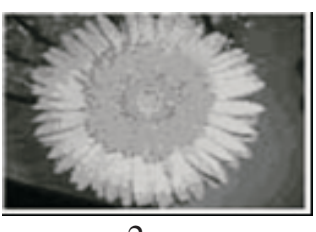

2

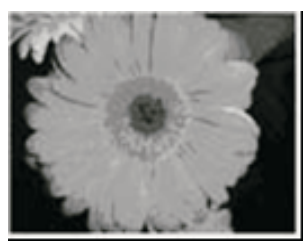

3 Malibu variety

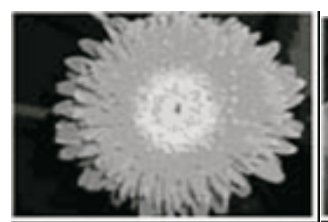

Sunway variety

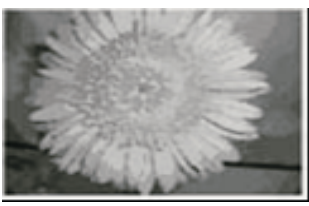

3

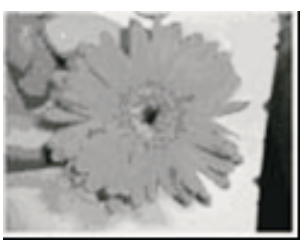

4
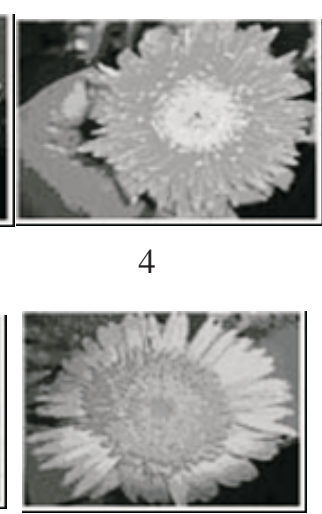

4

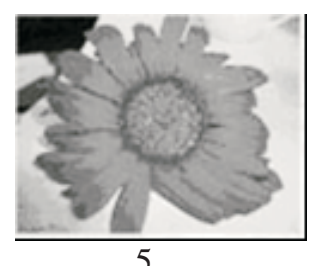

5

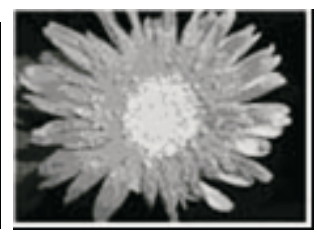

5

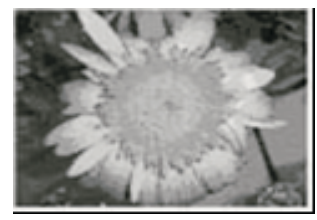

5

\section{Results and Discussion}

Fig. 1. Visual grading score for the vase life of gerbera varieties

\section{Vase life variation of gerbera in different} seasons

Influence of seasons was highly significant $(\mathrm{P}<0.001)$ on the vase life of gerbera cut flowers (Table 1$)$. Longest vase life (18.37 days) was found with the flowers harvested in winter, followed by harvested in spring (14.8 days) and autumn season (9.57 days). There was statistical variation among the influence of different seasons on vase life of the cut flower. Kumar and Kumar (2000) reported that vegetative and floral characteristics of gerbera cultivars varied in different months owing to the variable production environment prevalent during those periods. Pettersen and Gislerod (2003) also reported that the reduced vase life of inflorescence grown at high temperature could be caused by low carbohydrate content.

Table 1. Influence of seasons on the vase life of gerbera varieties

\begin{tabular}{l|c}
\hline Seasons & Vase life (days) \\
\hline Autumn & $9.57^{\mathrm{c}}$ \\
Winter & $18.37^{\mathrm{a}}$ \\
Spring & $14.8^{\mathrm{b}}$ \\
LSD & 1.86 \\
SE m \pm & 5.464 \\
P value & $<0.001$ \\
CV \% & 14.33 \\
\hline
\end{tabular}

$1 * * *$ Significant at $\mathrm{P}<.001$. Means within columns followed by the same letter are not significantly different at $5 \%$ level by Duncans Multiple Range Test

\section{Variation in vase life of gerbera varieties}

Influence of varieties on the vase life of gerbera cut flowers was found highly significant $(\mathrm{P}<0.001)$ (Table 2). Longest vase life (18.7 days) was found in Sunway variety, followed by Primrose (13.23 days) and Malibu variety (10.8 days). It was found that there was statistical variation among the influence of different varieties on vase life of gerbera cut flower. Concerning to the varietals performance on vase life, Sarkar \& Ghimiray (2004) reported that shelf life of cut flowers was longer in Sunway (23.15) followed by Vital (21.05) and Sangria (20.15), while that of Kalimpong Red (13.17) followed by Kalimpong Yellow (14.25) lasted for shorter period.

Table 2. Influence of varieties on the vase life of gerbera

\begin{tabular}{l|c}
\hline Varieties & Vase life (days) \\
\hline Primrose & $13.23^{\mathrm{b}}$ \\
Malibu & $10.8^{\mathrm{c}}$ \\
Sunway & $18.7^{\mathrm{a}}$ \\
$\mathrm{LSD}$ & 1.538 \\
$\mathrm{SE} \mathrm{m} \pm$ & 4.164 \\
$\mathrm{P}$ value & $<0.001$ \\
$\mathrm{CV} \%$ & 14.33 \\
\hline $1 * * *$ Significant at P <.001. Means within columns followed \\
by the same letter are not significantly different at 5\% level \\
by Duncans Multiple Range Test
\end{tabular}




\section{Interaction effect of seasons and varieties on vase life of gerbera}

Interaction effect of seasons and varieties on vase life of gerbera was found non-significant (Table 3). However, longest vase life (23.2 days) was found in Sunway variety harvested in winter season whereas the shorter vase lives (5.7 and 7.8 days) were found in Malibu and Primrose variety respectively harvested in autumn season. Statistically similar vase life was found in Sunway (17.7 days) and Primrose (17.4 days) variety harvested in winter and spring season respectively.

Table 3. Interaction effect of seasons and varieties on vase life of gerbera

\begin{tabular}{l|c|c|c|c}
\hline \multirow{2}{*}{\multicolumn{1}{c|}{ Seasons }} & \multicolumn{3}{c|}{ Vase life (days) } & \multirow{2}{*}{ Seasons mean } \\
\cline { 2 - 4 } & & Variety & Sunway & \\
\cline { 2 - 4 } & Primrose & Malibu & $15.2^{\mathrm{bc}}$ & 9.57 \\
Autumn & $7.8^{\mathrm{e}}$ & $5.7^{\mathrm{e}}$ & $23.2^{\mathrm{a}}$ & 18.37 \\
Winter & $17.4^{\mathrm{b}}$ & $14.5^{\mathrm{cd}}$ & $17.7^{\mathrm{b}}$ & 14.8 \\
Spring & $14.5^{\mathrm{cd}}$ & $12.2^{\mathrm{d}}$ & & \\
Variety mean & 13.23 & 10.8 & & \\
LSD & 2.664 & & \\
SE m \pm & 4.164 & & & \\
P value & 0.1558 & & & \\
CV\% & 14.33 & & & \\
\hline
\end{tabular}

Seasonal variation on initial stalk length, stalk diameter and floral diameter of different gerbera varieties

Seasonal variation on initial stalk length, stalk diameter and floral diameter of different gerbera varieties were all found highly significant $(\mathrm{P}<0.001)$ (Table 4). In Primrose variety, highest stalk length $(52.09 \mathrm{~cm})$ was found grown in autumn season, followed by grown in winter $(48.75 \mathrm{~cm})$ and spring season $(37.41 \mathrm{~cm})$. As in case of Malibu and Sunway varieties, same trend was found in stalk length variation. Highest stalk lengths (57.88 and $47.05 \mathrm{~cm}$ ) were found in Malibu and Sunway respectively, grown in autumn season followed by in winter (44.65 and $41.25 \mathrm{~cm}$ respectively) and lowest stalk length was found grown in spring season (35.44 and 32.02 cm respectively). It was reported that the longest stalk length $(37.67 \mathrm{~cm})$ was recorded in cv. Blorosa while the shortest $(30.78 \mathrm{~cm})$ in cv. Liabella. Among different months, the longest stalk length $(43.46 \mathrm{~cm})$ was recorded in September 1997 and shortest (27.79 cm) in January 1998 (Kumar \& Kumar 2000). They also explained that this variation might be due to the fact that stalk length varied with season, being shorter in cooler season. Similar type of results had been found elsewhere (Kim et al. 1990, Shin et al. 1994).
As in case of stalk diameter variation, in Primrose variety, highest stalk diameter $(0.52 \mathrm{~cm})$ was found grown in spring season, followed by grown in autumn $(0.48 \mathrm{~cm})$ and winter season $(0.46 \mathrm{~cm})$. In Malibu, highest stalk diameter $(0.48 \mathrm{~cm})$ was found grown in spring season followed by in autumn $(0.42$ $\mathrm{cm})$ and winter season $(0.41 \mathrm{~cm})$. Similarly, in Sunway, highest stalk diameter $(0.64 \mathrm{~cm})$ was found grown in spring, followed by in winter $(0.61 \mathrm{~cm})$ and in autumn season $(0.56 \mathrm{~cm})$. It was concluded that the diameter of the stem and inflorescence of gerbera decreased by 19 and $6 \%$ respectively as the temperature increased from 18 to $27^{\circ} \mathrm{C}$ (Pettersen \& Gislerod 2003).

With respect to floral diameter variation, in Primrose and Sunway varieties, highest floral diameters (9.45 and $10.78 \mathrm{~cm}$ respectively) were found grown in autumn season followed by grown in winter (9.43 and $9.59 \mathrm{~cm}$ respectively) and in spring season (9.10 and $9.01 \mathrm{~cm}$ respectively). In Malibu, highest floral diameter $(8.31 \mathrm{~cm})$ was found in gerbera cut flowers which was grown in autumn season and followed by $7.65 \mathrm{~cm}$ floral diameter both in spring and winter season. Kumar and Kumar (2000) reported that vegetative and floral characteristics of gerbera cultivars varied in different months owing to the variable production. 
Anil Kumar Acharya et al./Influence of Seasons an.......

Table 4. Seasonal variation on initial stalk length, stalk diameter and floral diameter of different gerbera varieties

\begin{tabular}{l|c|c|c|c|c|c|c|c|c}
\hline \multirow{2}{*}{ Seasons } & \multicolumn{3}{|c|}{ Stalk length } & \multicolumn{3}{c|}{ Stalk diameter } & \multicolumn{3}{c}{ Floral diameter } \\
\hline & $\mathbf{P}$ & $\mathbf{M}$ & $\mathbf{S}$ & $\mathbf{P}$ & $\mathbf{M}$ & $\mathbf{S}$ & $\mathbf{P}$ & $\mathbf{M}$ & $\mathbf{S}$ \\
\hline Autumn & $52.09^{\mathrm{b}}$ & $57.88^{\mathrm{a}}$ & $47.05^{\mathrm{cd}}$ & $0.48^{\mathrm{de}}$ & $0.42^{\mathrm{ef}}$ & $0.56^{\mathrm{bc}}$ & $9.45^{\mathrm{b}}$ & $8.31^{\mathrm{c}}$ & $10.78^{\mathrm{a}}$ \\
Winter & $48.75^{\mathrm{bc}}$ & $44.65^{\mathrm{de}}$ & $41.25^{\mathrm{e}}$ & $0.46^{\mathrm{ef}}$ & $0.41^{\mathrm{f}}$ & $0.61^{\mathrm{ab}}$ & $9.43^{\mathrm{b}}$ & $7.65^{\mathrm{d}}$ & $9.59^{\mathrm{b}}$ \\
Spring & $37.41^{\mathrm{f}}$ & $35.44^{\mathrm{fg}}$ & $32.02^{\mathrm{g}}$ & $0.52^{\mathrm{cd}}$ & $0.48^{\mathrm{de}}$ & $0.64^{\mathrm{a}}$ & $9.10^{\mathrm{b}}$ & $7.65^{\mathrm{d}}$ & $9.01^{\mathrm{b}}$ \\
LSD & & 3.771 & & & 0.05761 & & 0.5918 & & \\
SE m \pm & & 8.569 & & & 0.002 & & 0.211 & \\
P value & & $<0.001$ & & & $<0.001$ & & $<0.001$ & & \\
CV\% & & 6.64 & & & 8.47 & & 5.10 & & \\
\hline
\end{tabular}

$1 * * *$ Significant at $\mathrm{P}<.001$. Means within columns followed by the same letter are not significantly different at $5 \%$ level by Duncans Multiple Range Test. $\mathrm{P}=$ Primrose, $\mathrm{M}=$ Malibu and $\mathrm{S}=$ Sunway variety

\section{Influence of seasons on water uptake variation in vase life of gerbera}

Influence of seasons on water uptake variation in vase life of gerbera is presented in Fig. 2. Highest water uptake in vase life (7.65 $\mathrm{ml}$ at 2nd day and $16.56 \mathrm{ml}$ up to 6th days) was found in flowers grown in winter, followed by autumn $(5.76 \mathrm{ml}$ at 2nd day and $13.17 \mathrm{ml}$ up to 6th days) and spring (5.2 $\mathrm{ml}$ at 2 nd day and 12.6 $\mathrm{ml}$ up to 6th days). With respect to the total water uptake in the vase life, highest total water uptake was found in flowers grown in winter $(34.88 \mathrm{ml})$ followed by spring $(34.7 \mathrm{ml})$ and autumn $(26.14 \mathrm{ml})$. Highest total water uptake might be correlated with the vase life of the flowers. It could be explained by observing Table 1 where highest vase life was in winter, followed by spring and autumn.

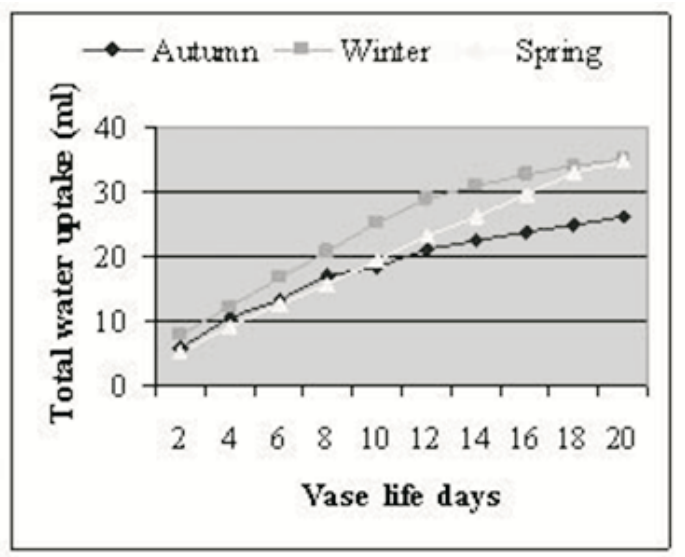

It was found that there was highest water uptake at 2nd day of vase life in each season thereafter there were drastically decrease in water uptake until 4th to 6 th days of vase life. Moreover, parallel to decreasing water uptake trend was found from 6th to 12th days of vase life. It was reported that water uptake by cut chrysanthemum flowers varied with the season and lignification of stem (Marousky 1973). He suggested that products associated with lignification impaired water uptake. Similarly in roses and other cut flowers, it was reported that after cutting, water loss decreased sharply due to stomatal closure (Mayak et al. 1974); water loss then paralleled water uptake (Burdett 1970, Halevy et al. 1974) and finally an increase in water loss occurred before wilting (Hsiang 1951, Halevy et al. 1974, Van Meeteren 1978).

Fig. 2. Water uptake variation in vase life of different seasons 
Based on the conducted research on gerbera cut flowers, it can be concluded as

- Sunway variety had the longest vase life, followed by Primrose and Malibu. The variation among cultivars might be due to different varietal behaviour and their interaction with the production environment. Durability of flowers among the cultivars can be attributed to the genetic makeup of the cultivars.

- Longest vase life was found with the flowers harvested in winter, followed by harvested in spring and autumn season. Vegetative and floral characteristics of gerbera cultivars varied in different months owing to the variable production environment prevalent during those periods.

\section{Acknowledgements}

The authors are thankful to the Seed Quality Control Centre, Ministry of Agriculture and Cooperatives, Hariharbhawan for providing us the controlled laboratory and other accessories for the research work. First author would like to express sincere thanks to the National Agriculture Research and Development Fund (NARDF), Kathmandu for providing financial support for his M. Sc. thesis research.

\section{References}

Burdett, A.N. 1970. The cause of bent neck in cut roses. Journal of American Society of Horticulture Science 95: 427-431.

Choudhary, M.L. and K.V. Prasad. 2000. Protected cultivation of ornamental crops- An insight. Indian Horticulture 45:49-53.

Emongor, V.E. 2004. Effects of gibberellic acid on postharvest quality and vase life of gerbera cut flowers (Gerbera jamesonii). Journal of Agronomy 3:191-195.

FAN. 2007. Trade competitiveness of the floriculture sub sector in Nepal. Floriculture Association Nepal/Agro Enterprise Centre, FNCCI, Kathmandu, Nepal.

FAN. 2010. Floriculture Trade Fair Souvenir. Floriculture Association Nepal, FNCCI Building, Teku, Kathmandu, Nepal.

Gomez, K. and A. Gomez. 1984. Statistical procedure for agriculture research. 2nd edition. A Wiley Interscience Publication. John Wiley and Sons, New York. 108 pp.

Halevy, A.H., S. Mayak, T. Tirosh, H. Spiegelstein and A.M. Kofranek. 1974. Opposing effects of abscissic acid on senescence of rose flowers. Plant \& Cell Physiology 15:813-821.

Hsiang, T.H.T. 1951. Physiological and biochemical changes accompanying pollination in orchid flowers. I. General observations and water relations. Plant Physiology 26: 441-555.

Kim, J.Y., Y.P. Hong, H.K. Shin and R.W. Shin. 1990. Studies on the cultivation of year-round cut flower in gerbera. Research reports of the rural development administration (Horticulture) 32:36-48.

Kumar, D. and R. Kumar. 2000. Seasonal response on gerbera cultivars. Journal of Ornamental Horticulture 3:103-106.

Marousky, F.J. 1973. Recent advances in opening budcut-chrysanthemum flowers. HortScience 8:199-202.

Mayak, S., A.H. Halevy, S. Sagie, A. Bar-Yoseph and B. Bravdo. 1974. The water balance of cut rose flowers. Physiologia Plantarum 32:15-22.

Meman, M.A. and K.M. Dabhi. 2006. Effect of different stalk lengths and certain chemical substances on vase life of gerbera (Gerbera jamesonii Hook.) cv. 'Savana Red'. Journal of Applied Horticulture 8:147-150.

MOAC. 2009. Statistical information on Nepalese agriculture, 2008/2009. Ministry of Agriculture and Cooperatives, Kathmandu, Nepal.

Nair, S.A., V. Singh, T.V.R.S. Sharma. 2003. Effect of chemical preservatives on enhancing vase-life of gerbera flowers. Journal of Tropical Agriculture 41:56-58.

Pettersen, R.I. and H.R. Gislerod. 2003. Effects of lighting period and temperature on growth, yield and keeping quality of Gerbera jamesonii. European Journal of Horticulture Science 68:32-37.

Sarkar, I. and T.S. Ghimiray. 2004. Performance of gerbera under protected condition in hilly region of West Bengal. Journal of Ornamental Horticulture 7:230-234.

Shin, H.K., J.Y. Kim, R.W. Shin and Y.K. Ko. 1994. Seasonal fluctuation of yield and quality of cut flowers in gerbera hybrids. Journal of Agriculture Science, Horticulture 36:444-452.

UNCTAD/WTO. 2007. Export potential assessment in Nepal. International Trade Centre, UNCTAD/WTO, Nepal.

Van Meeteren, U. 1978. Water relations and keepingquality of cut gerbera flowers I. The cause of stembreak. Scientia Horticulturae 8:65-74.

Wernett, H.C., T.J. Sheehan, G.J. Wilfret, P.M. Marousky, P.M. Lyrene, and D.A. Knauft. 1996. Postharvest longevity of cut flower gerbera. Response to section for vase life components. Journal of American Society of Horticulture Science 121:216-221. 